\section{ЛЕТОПИСЬ СОВЕТСКОЙ ТУВЫ 1950-1960-х гг. В ДНЕВНИКАХ САЛЧАКА ТОКА}

\section{Григорий Ч. Шириин}

Независимый автор, Российская Федерация

\section{A CHRONICLE OF THE SOVIET TUVA (1950s-1960s) IN THE DIARIES OF SALCHAK TOKA}

\author{
Grigorii Ch. Shirshin \\ Independent author, \\ Russian Federation
}

В статье представлен авторский анализ дневниковых записей Салчака Калбакхорековича Тока (1901-1973), известного государственного и общественного деятеля Республики Тыва, первого секретаря ЦК Тувинской народно-революционной партии (1932-1944); первого секретаря Тувинского обкома КПСС (1944-1973). Его деятельность достаточно освещена в научной литературе, как в советский период, так и в последние годы. В 2012 г. общественность республики отмечала 110-летие со дня его рождения, проводилась отдельная научная конференция.

Особую ценность для изучения деятельности С.К. Тока после вступления Тувы в состав СССР имеют его дневниковые записи - более 20 блокнотов 1954-1964 г2., которые автор делал на русском языке. Они были переданы автору статьи супругой Х. А. Анчима-Тока и хранятся ныне в его личном архиве. Сам автор был преемником С. К. Тока на посту первого секретаря Тувинского обкома КПСС (1973-1991).

Записи в блокнотах отражают деятельность С. К. Тока, его руководящий стиль, методы работы, его убеждения. Приведены отрывки из записей: о людях, о быте, о промышленности, об идеологиче-

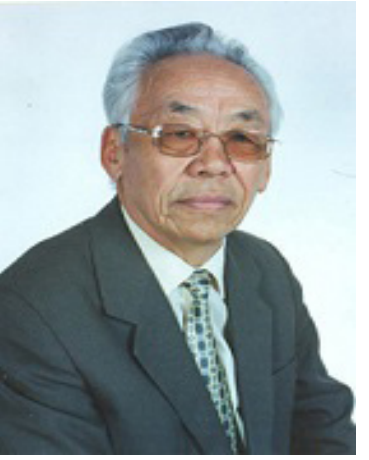

The article examines the diaries of Salchak Kalakbakhorekhovich Toka (1901-1973), a prominent statesman and public figure of the Republic of Tuva, First Secretary of the Central Committee of Tuva People's Revolutionary Party (1932-1944), First Secretary of Tuva Oblast Committee of the CPSU (19441973). Toka's work as a party official has been covered in detail by historians, both in the Soviet and post-Soviet periods. In 2012, his 110th anniversary was celebrated in the region, and a dedicated research conference was held to honor him.

$S$. K. Toka's diaries are an invaluable resource for researchers of his life and work after Tuva's accession to the USSR. Over 20 notebooks with diary entries from 1954 to 1964, written in Russian, were given to the author by Kh. A. Anchima-Toka, S.K. Toka's widow, and have been preserved by the author, who succeeded S.K. Toka as First Secretary (1973-1991).

The diary entries reflect $S$. K. Toka's personal workstyle, his methods of management and personal views. The article showcases several diary fragments, including his opinions on people, everyday life in Tuva, its industries, ideological

Ширшин Григорий Чоодуевич - кандидат исторических наук, независимый автор; первый секретарь Тувинского республиканского комитета КПСС (1973-1990); г. Кызыл, Российская Федерация. Эл. адрес: igi@tuva.ru

Shirshin Grigory Chooduevich, Candidate of History, Independent author; First Secretary, Tuva Republic committee of the Communist Party of the Soviet Union (1973-1990), Kyzyl, Russian Federation. E-mail: igi@tigpi.ru 
ской работе, о работе школ и учителей. Материал иллюстрирован отсканированными копиями отдельных странии дневников, показывающих как особенности письма автора, так и характер записей.

Ключевые слова: Салчак Калбакхорекович Тока; Тува; советская история; личность в истории; дневники; история Тувы work of the Communist Party, Tuva's schools and teachers. Also provided are the photocopies of several diary pages, which illustrate both the nature of the entries and the specific features of the diarist's style.

Keywords: Salchak Kalbakhorekhovich Toka; Tuva; Soviet history; personality in history; diaries; history of Tuva

\section{Введение}

Эпохальные прогрессивные изменения в новейшей истории Тувы - ее добровольное вхождение в состав Советского Союза в 1944 г. с образованием Тувинской автономной области, в последующем - ее преобразование в Тувинскую АССР в 1961 г. теснейшим образом связаны с именем Салчака Калбакхорековича Тока (1901-1973). Именно в этот исторический период в деле нового жизнеустройства тувинского народа в полной мере раскрылся его организаторский талант, как крупного руководителя и организатора народных масс.

Многогранная политическая и организаторская деятельность С. К. Тока достаточно освещена в научной литературе, как в советский период, так и в последние годы - соответственно оценки его деятельности высказывались разные (см.: Аранчын, 1982; Москаленко, 2002; Ламажаа, 2010; Байыр-оол, 2009, 2010, 2011). В 2012 г. общественность республики, в том числе научная, отмечала 110-летие со дня его рождения. Проведение отдельной конференции к этой дате знаменует новый виток исследовательского интереса к личности тувинского политика (см.: Салчак Тока ..., 2012: Электр. ресурс).

Начальный путь биографии Салчака Калбакхорековича многие прекрасно знают благодаря тому, что сам он являлся творческим человеком и писателем, рассказав о себе в романе «Слово арата» (Тока, 1951). Поздние же годы его деятельности - общественно-политической - С. К. Тока также описывал, однако, эти записи вел только в дневниках, которые не были изданы и часть из которых - более 20 блокнотов за 1954-1964 гг. хранятся в моем личном архиве. Они были переданы мне его супругой Хертек Амырбитовной Анчима-Тока в июне 2007 г. Она заботливо приводила в порядок архивные документы супруга, включая эти блокноты, которые сохранены и аккуратно пронумерованы по месяцам и годам.

Может возникнуть вопрос о том, почему именно мне они были переданы? Здесь ответ может быть следующий. Хертек Амирбитовна как человек умный, дальновидный понимала, что долго хранить блокноты дома нецелесообразно по многим причинам, в том числе они по истечению времени могут просто поте- 
ряться. При их передаче она мне доверительно сказала: «Я только вам передаю их на хранение и изучение, что дальше будете делать с ними - сами решите».

Будучи секретарем обкома КПСС, я хорошо знал Хертек Амырбитовну по совместной работе, связанной с решением проблем в различных сферах социально-культурной жизни республики. Я чувствовал всегда ее доброе человеческое отношение ко мне и моей семье. Поэтому догадывался, что при передаче мне блокнотов С. К. Тока она руководствовалась только искренними мотивами.

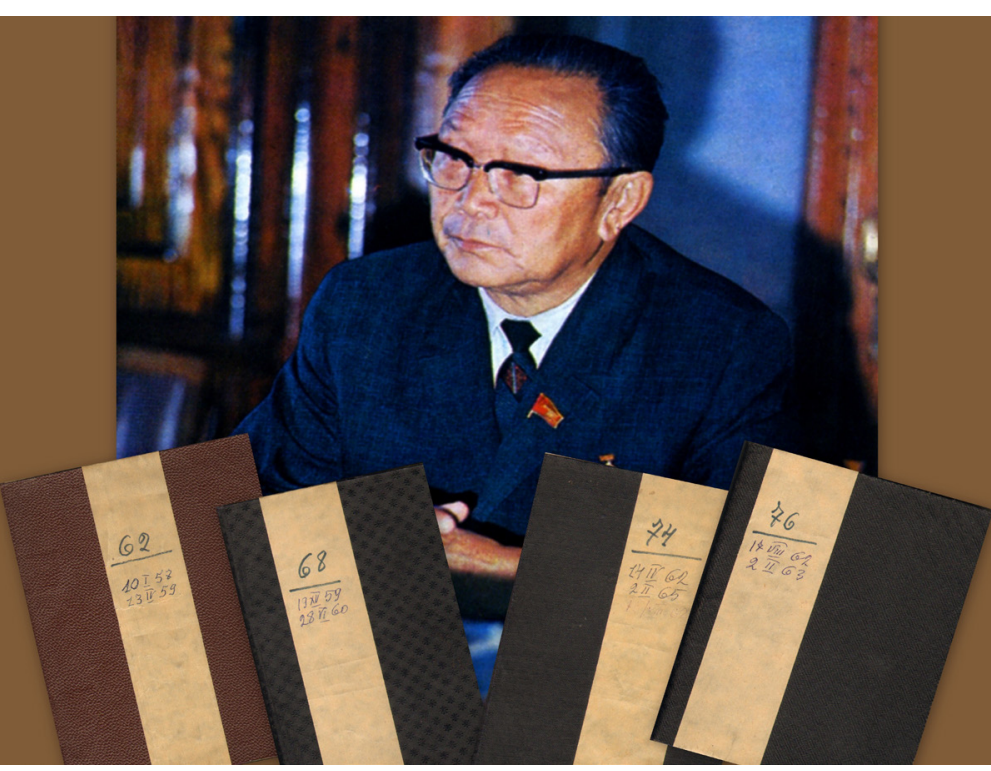

Рис. 1. Коллаж фото С. К. Тока и обложек некоторых его дневников.

Fig.1. A photograph of S.K. Toka and the covers of some of his diary books

Блокноты С. К. Тока с записями (рис. 1) можно рассматривать как летопись его многосторонней политической и организаторской деятельности по осуществлению коренных преобразований в жизни Советской Тувы. Блокноты отражают характер, содержание и последовательность этой деятельности. В них - его творческий стиль и методы работы, и, наконец, масштабное, комплексное решение задач всех сфер жизни.

В данной статье я представлю, что именно писал С. К. Тока в своих дневниках за указанные годы и приведу цитаты из записей, таким образом вводя в научный оборот ценнейший материал об одном из самых известных общественно-политических деятелей Тувы XX века.

\section{Интерес к людям}

Все записанное в блокнотах показывает тесную связь С. К. Тока с народом. Постоянные контакты и общение с различными слоями населения - это основные принципы его деятельности. Они позволяли ему лично видеть и понимать дела и заботы людей. Близкое знакомство с их жизнью и трудом помогало находить подходы к решению наиболее насущных текущих, в то же время общих проблем развития, что являлось на практике его большой приземленной политикой. Это особенно зримо и ярко просматривается в первые советские годы.

Из записок видно: ему очень хотелось как можно быстрее изменить в лучшую сторону жизнь аратских масс, которые в те времена еще были разобщены, слабо были ориентированы в новых общественно-экономических условиях. 
Где только он не бывал, чем только не интересовался! Его интересы касались и качества юрт, и «русских» печей (кирпичные), и умывальников в домах, стекол для окон, осветительного керосина для ламп, товаров для повседневных нужд, колодцев и скважин, дорог, транспорта и связи... По записям можно проследить, как С. К. Тока хорошо понимал важность налаживания и обеспечение повседневных житейских нужд и запросов, и что это в свою очередь будет способствовать и укреплять веру и уверенность аратов в новой жизни, новой организации труда, объединении усилий.

Например, в дневнике № 62, в котором содержатся записи от 10 января 1957 г. до 13 декабря 1959 г., есть запись (рис. 2):

«Утром 27/XI.58 г. в с. школе, в интернатах грязновато, успеваемость 32\%, двери в интернате мал. дверь выл.

Был в больнице. Мало мягкого белья, машину ГАЗик дали старый, нет у женщин нижнего белья»

(здесь и далее в цитатах орфография источника сохранена. - pед.).

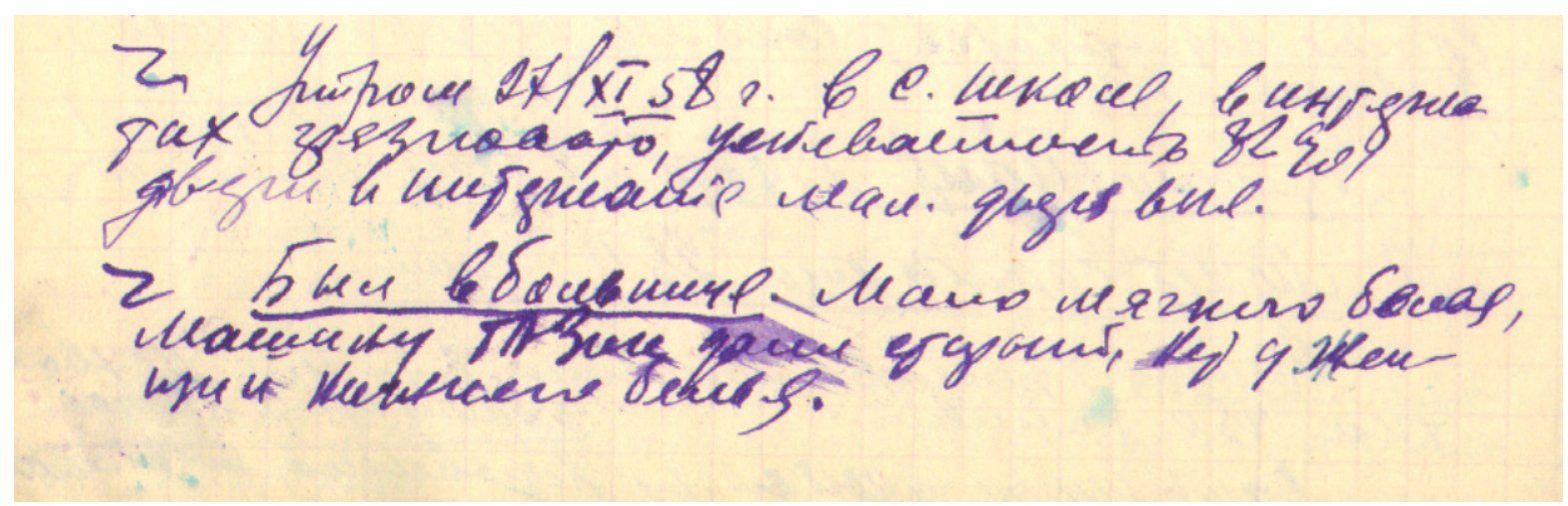

Рис. 2. Отрывок из записи дневника № 62 (10.01.1957-13.04.1959) о посещении школы и больницы 27 ноября 1958 г.

Fig.2. A fragment of an entry describing a visit to a school and a hospital, diary No. 62 (10.01.1957-13.04.1959)

Особое внимание он уделял вопросам дисциплины и ответственности - в труде, в конкретных делах, в общении по важным вопросам. В замечании (без даты) в дневнике № 62 есть такая запись:

«Замечание. Пленум проводят не организовано, в зале шум, выкрикивания, одновременно разговаривают по 2-3 человека. Отдельные т. т. не просидев и часу кричат «Перерыв!» В конце Пленума пришлось сделать замечание. Крайне не выдержанность показал т. Мучаев. Обвинил всех работников водхоза пъяницами...»

В записях начала 1950-х годов содержатся отдельные итоги развития Тувы, достигнутые за первые годы Советской власти. Этот период характеризовался 80 
активным переходом аратских масс на коллективные формы труда, на оседлый образ жизни. В непростых условиях были созданы не один десяток тожземов (товариществ по совместному ведению животноводства и земледелия) и колхозов практически в каждом сумоне (рис. 3).

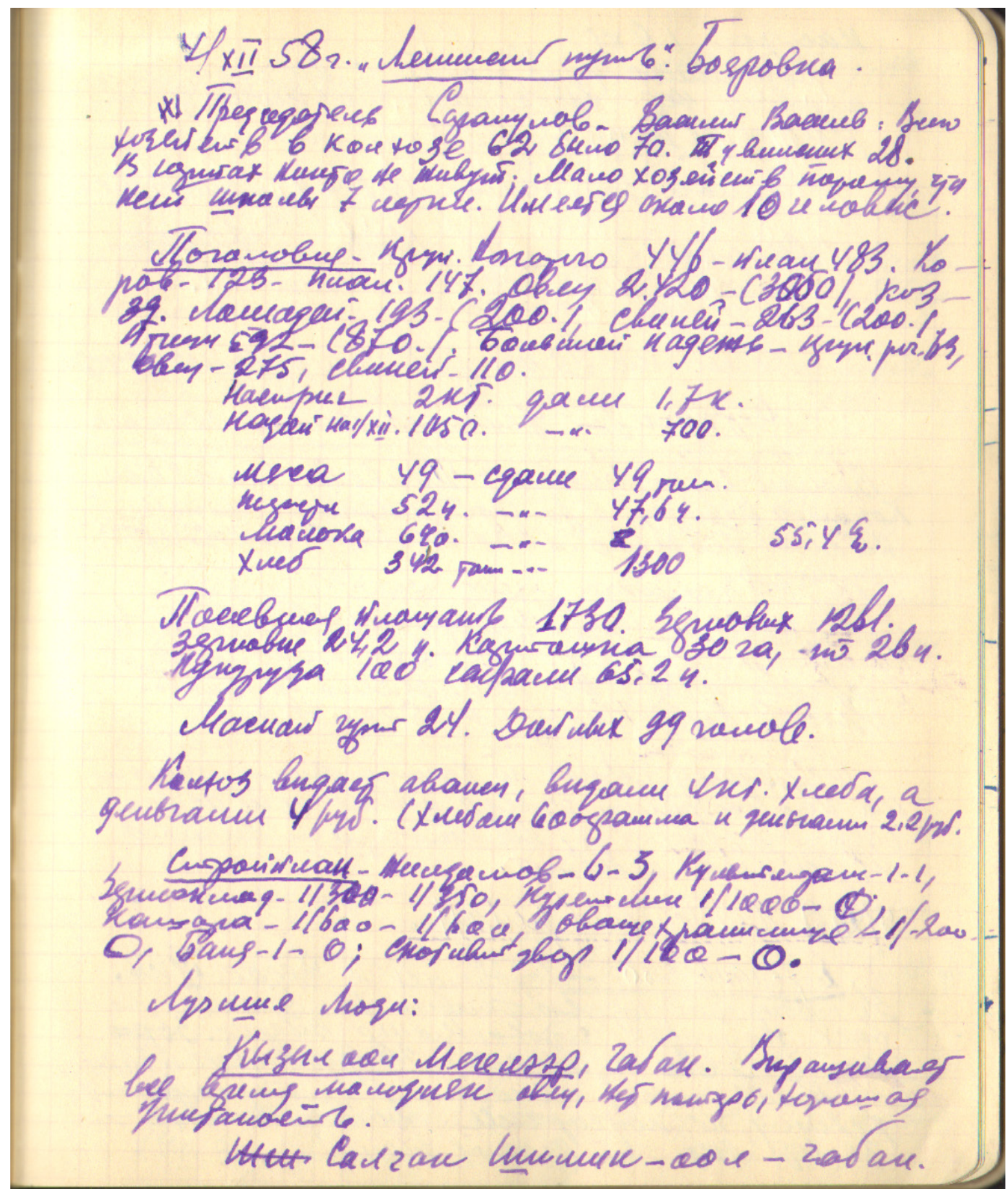

Рис. 3. Страница из дневника № 62 (10.01.1957-13.04.1959) о совещании в колхозе «Ленинский путь» в с. Бояровка 4 декабря 1958 г.

Fig. 3. A page from diary No. 62 (10.01.1957-13.04.1959) with an entry describing a meeting at the Leninskii Put' collective farm, s. Boyarovka, December 4, 1958 
В коллективной организации труда при нехватке кадров, и вообще в устройстве новой жизни, огромную помощь оказывали приехавшие из Советского Союза многочисленные посланцы, которые работали руководителями и специалистами вновь организуемых колхозов, первых очагов предприятий в других хозяйственно-экономических сферах. Их приезд во многом также был большой заслугой С. К. Тока.

Дневники свидетельствуют о том, что С. К. Тока хорошо понимал, что наряду с переходом аратов на кооперированную форму труда, необходимо развивать перерабатывающие отрасли, создание которых требовали нужды населения. Это направление работы становилось предметом особой заботы. Он регулярно посещал пищевые, торговые предприятия, настраивал их руководителей на лучшее использование имеющихся местных ресурсов, улучшение контроля за качеством собственных и завозимых продукций и товаров из-за Саян.

С созданием новых отраслей экономики и социальной сферы во второй половине 1950-х и в первой половине 1960-х гг. развитие Тувы приобретало новое качество. Постепенно формировалась современная аграрная отрасль народного хозяйства в составе крупных колхозов и совхозов (в 1971 г. их стало уже 58) с соответствующей материально-технической базой, со всеми социально-культурными структурами, необходимыми кадрами различных профессий. Они имели в 1971 г. свыше 1 млн 295 тыс. голов скота, 2494 тракторов различных марок, 1039 зерновых комбайнов, 1857 грузовых автомашин, много другой техники. Производили до 13 тыс. тонн мяса в убойном весе, 29 тыс. тонн молока, свыше 2000 тонн шерсти, более 200 тыс. тонн зерна, фактически полностью обеспечивали потребности населения республики (рис. 4).

В блокнотах содержится большое количество аккуратно записанных цифровых данных, причем в строгой последовательности по месяцам и годам: по общему объему производства продукции животноводства и земледелия в колхозах и совхозах, по районам, их сдачи государству, росту поголовья скота и его продуктивности, посевные площади и урожайность зерновых и кормовых культур, картофеля и овощей. Это - количество тракторов, комбайнов и автомашин, другой техники в самих хозяйствах и машинно-тракторных станциях (MTC), которые сыграли большую роль в механизации аграрной отрасли, а также рост и численность механизаторских кадров.

\section{Отрасли экономики}

Записи в блокнотах дают возможность видеть, как решались задачи становления Тувы на индустриально-промышленный путь развития. С. К. Тока четко понимал, что только активные меры по ускоренной интеграции экономики Тувы в хозяйственную жизнь страны, а также тесная связь с существовавшим в те годы 


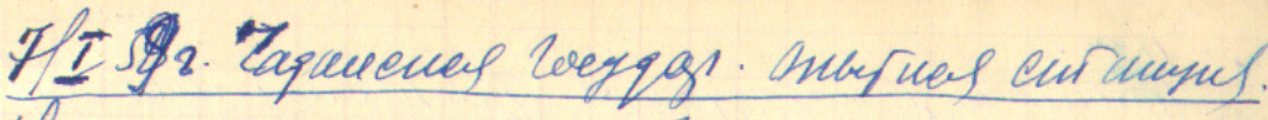

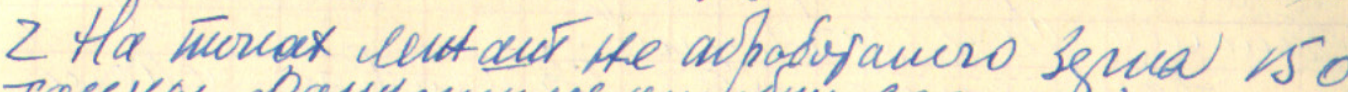

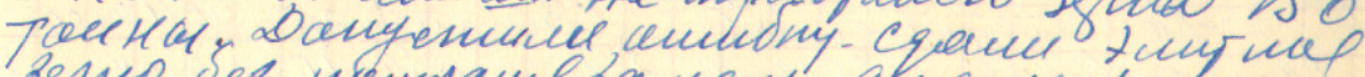

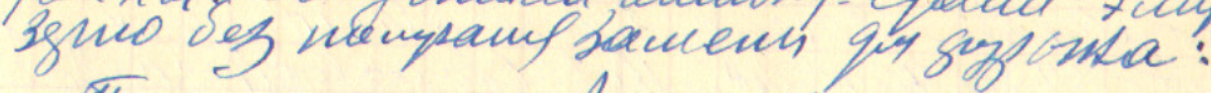

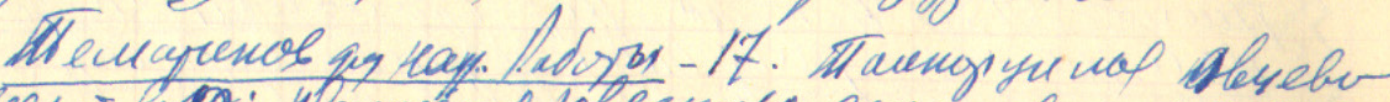

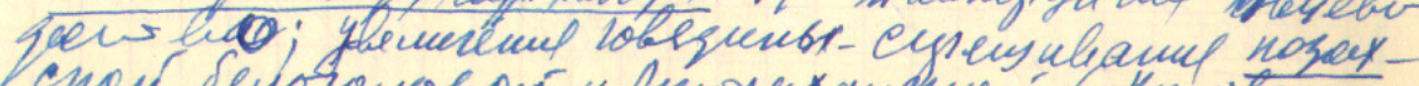

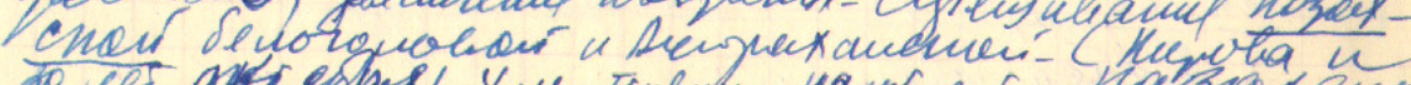

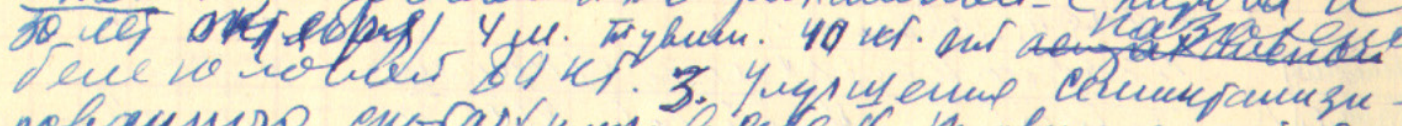

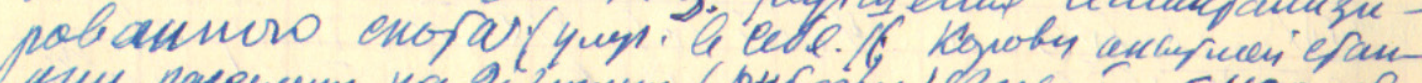

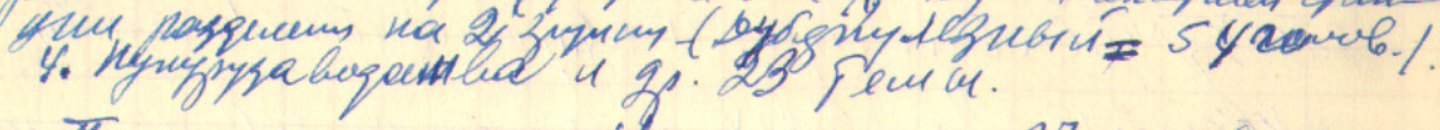

Terruany Hay. Tiex. 10-4ur mrer 27.

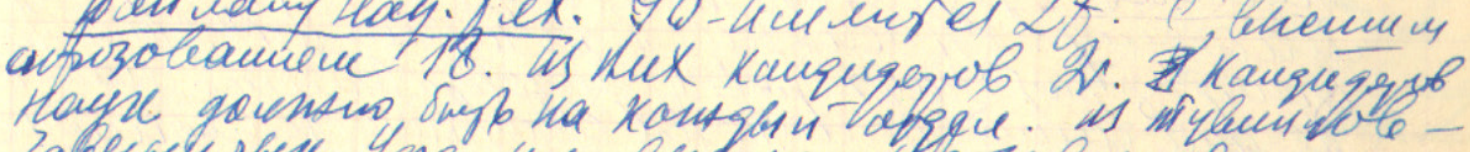

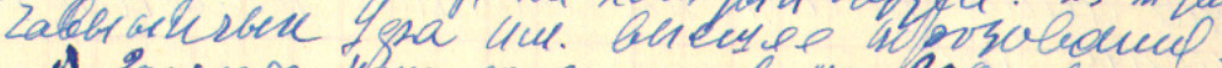

1). Egurvora hays ganpyquive Ha 20 bnise um 6

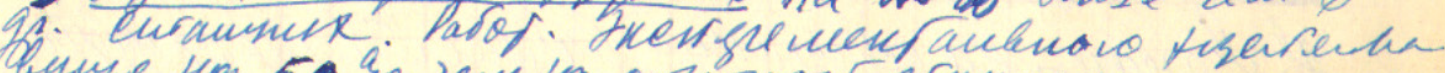

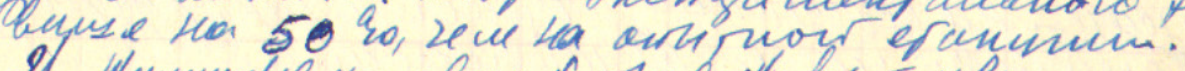

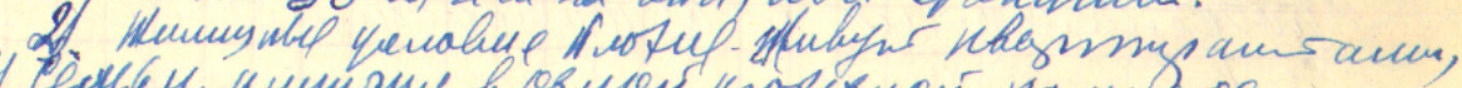

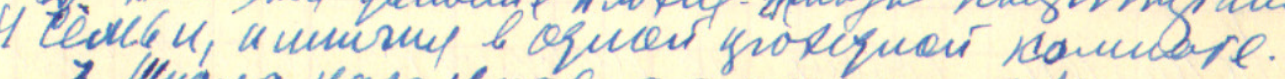

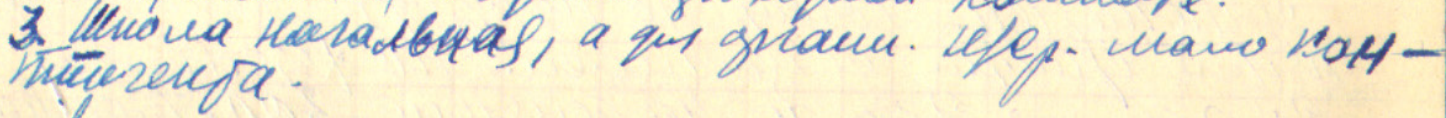

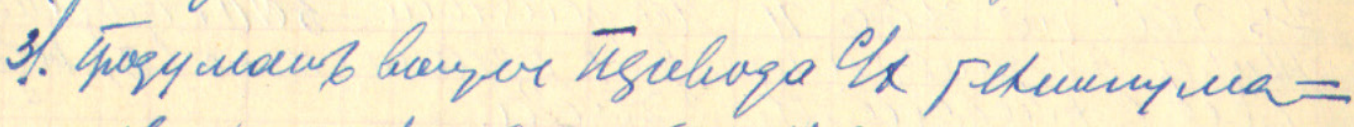

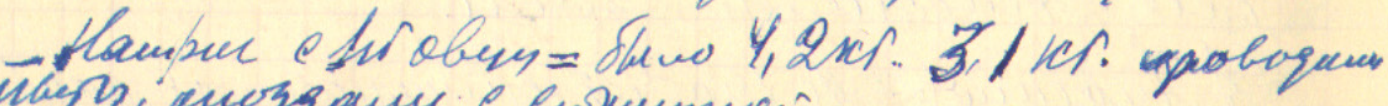

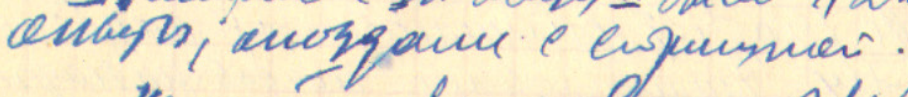

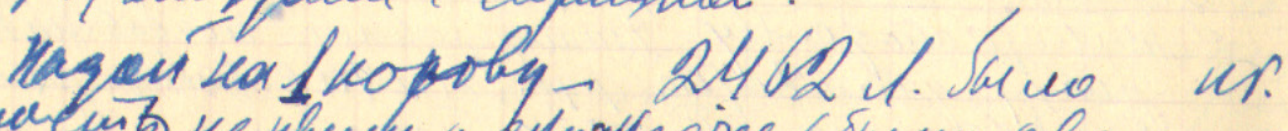
4.

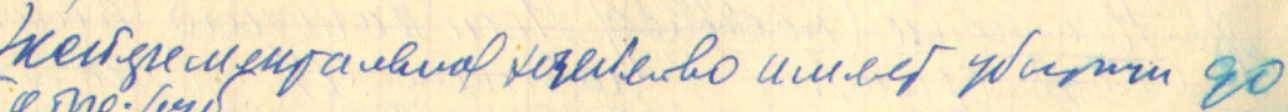
vice no.logis.

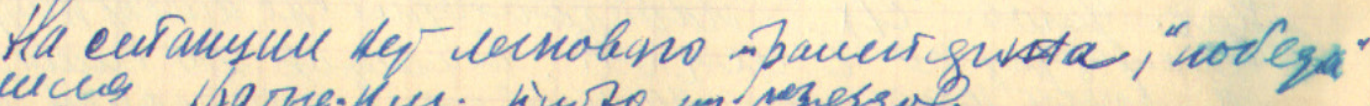

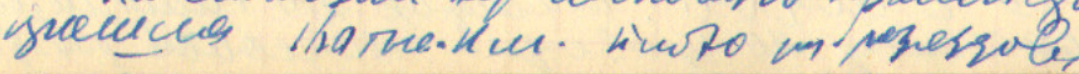

Рис. 4. Страница из дневника № 62 (10.01.1957-13.04.1959) о посещении Чаданской государственной опытной станции 7 января 1959 г.

Fig.4. A page from diary No. 62 (10.01.1957-13.04.1959) with an entry describing a visit to Chadan state experimental station, January 7, 1959. 
Советом Народного хозяйства Сибири, соседними областями, республиками и краями позволит успешно решить поставленные задачи.

Записи от 5 июля 1962 г.

«Промышленность:

- Все предприятия дали рост на 108,1\% или на 630,3 тыс. руб. больше плана, против прош. года рост на 1.368,6 тыс. руб. 19,4\%:

- тор. руд. комб. 104,4\%, 79,3 тыс. руб. больше плана или на 486,3 тыс. $(35,1 \%)$ больше прошлого года....»

Вместе со своими коллегами, при поддержке центральных партийных, государственных и хозяйственных органов он систематически занимался вопросами строительства и ввода в эксплуатацию комбинатов «Туваасбест» (первая очередь), «Тувакобальт», Чаданского и Каа-Хемского угольных разрезов, ТерлигХаинского ртутного предприятия, Кызылского комбината строительных конструкций, швейной фабрики, мясомолочных заводов, а также жилья, школ, учреждений медицины, культуры и многих других объектов жизнеобеспечения.

Тока прилагал огромные усилия для решения вопроса подключения Тувы к единой энергетической системе Сибири в 1960 гг., что дало новый импульс электрификации населенных пунктов и объектов народного хозяйства, а также завершению строительства автодороги Ак-Довурак-Абаза, в результате которого республика получила второй выход к железнодорожным станциям юга Сибири.

С. К. Тока уделял постоянное внимание созданию в республике целостных современных систем здравоохранения, образования и культуры, с необходимой материально-технической базой и кадровым составом, которые относятся к числу важнейших преобразований, осуществленных в советские годы.

Непременным правилом для С. К. Тока являлось обязательное посещение больниц, медпунктов, школ, интернатов, детских дошкольных учреждений, домов культуры, клубов и библиотеки в период многочисленных поездок по районам. Он следил за работой творческих организаций интеллигенции: союзов писателей, композиторов, журналистов и художников, посещал театр, музей и выставки (см. рис. 5 и 6).

Не упускал возможности принять участие в значимых культурно-массовых мероприятиях, инициировал поощрение творческих работников, имеющих большие заслуги.

Запись от 24 августа 1962 г. (дневник № 76 за период 17.08.1962-02.02.1963 г.):

3. Совещание учителей гор. Кызыла ... Товарищи! После всех выступлений которые мы, с большим удоволетворением выслушали, как доклады, так и особенно выступления ораторов, трудно выступать и что либо добавить. Все вопросы касательно учения и воспитания детей, нашими школами, общественностью и родителями и очередные задачи были хорошо изложены. 
НОВЫЕ ИССЛЕДОВАНИЯ ТУВЫ

www.nit.tuva.asia

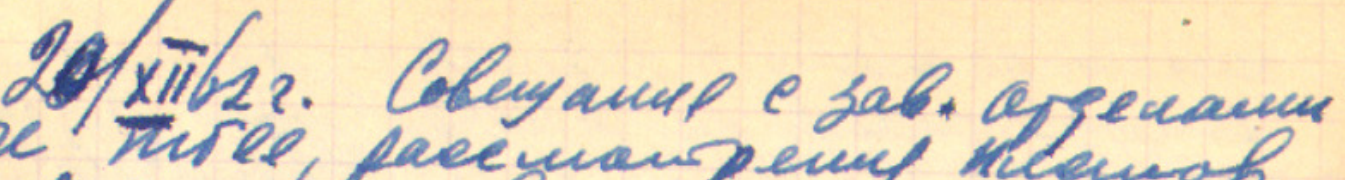

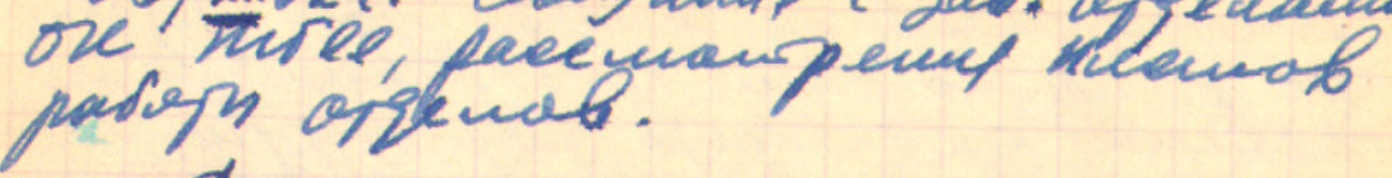

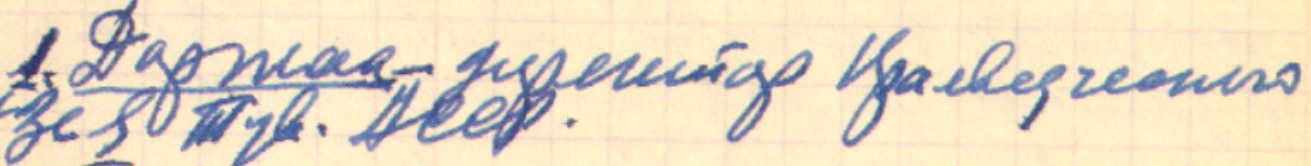

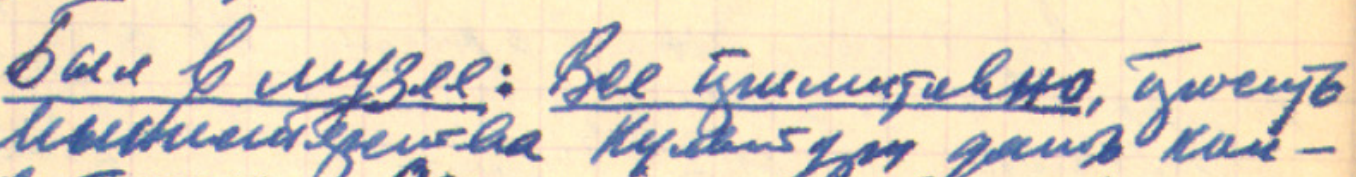

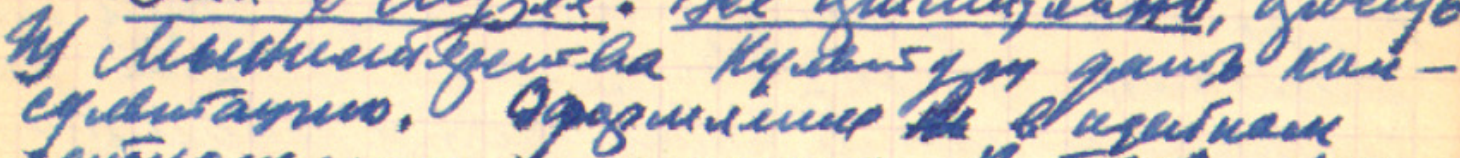

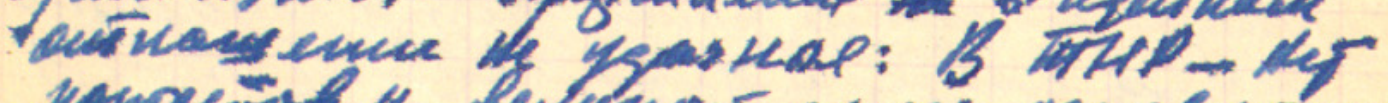

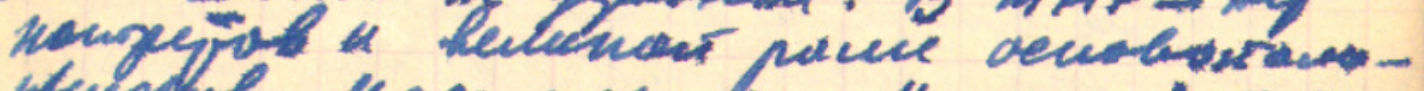

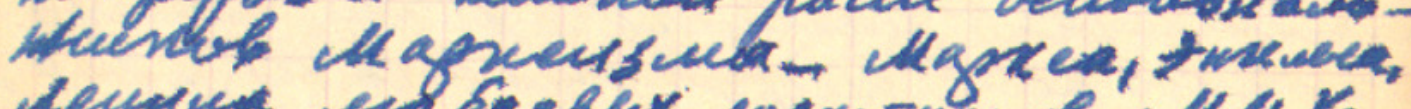

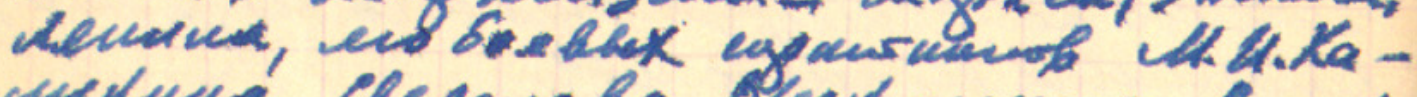

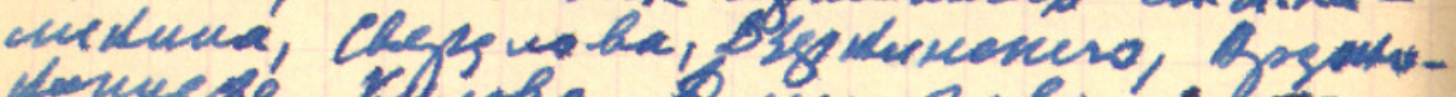

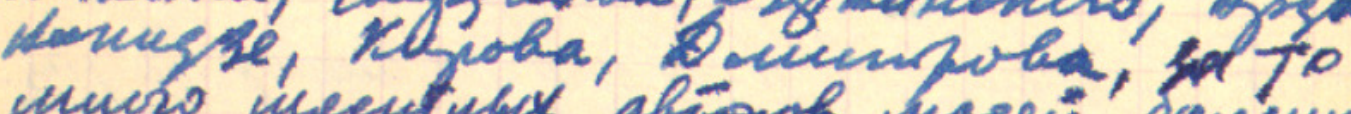

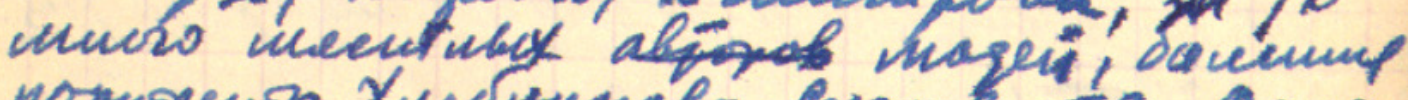

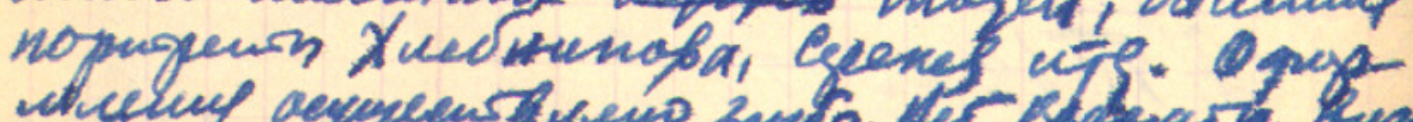

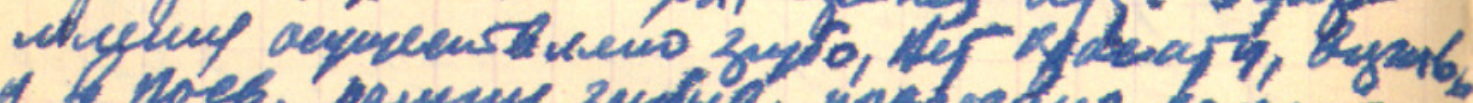

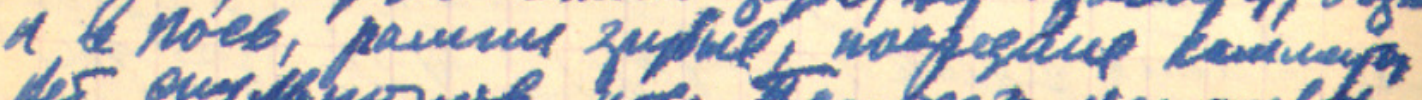

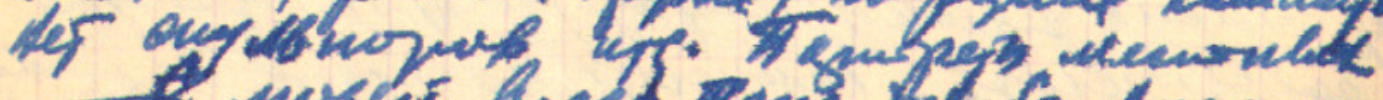

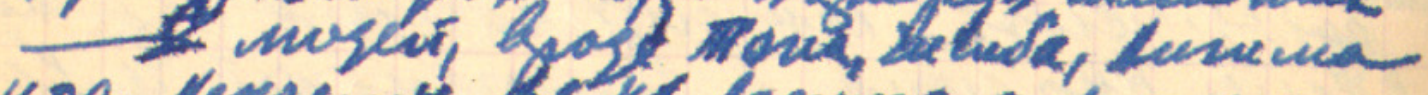

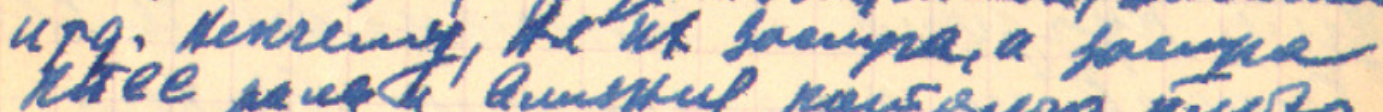

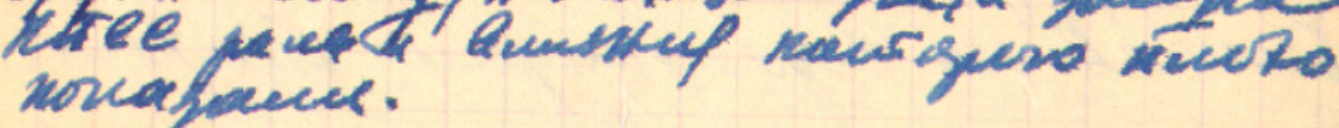

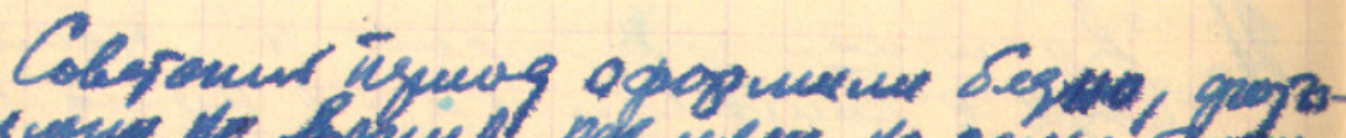

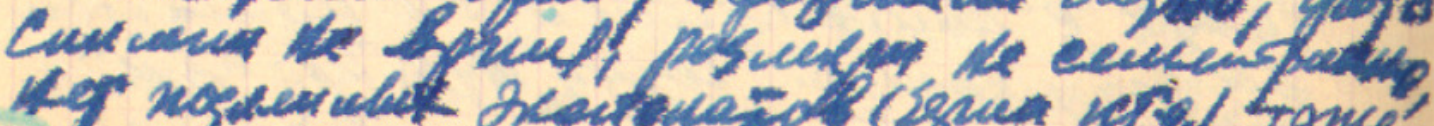

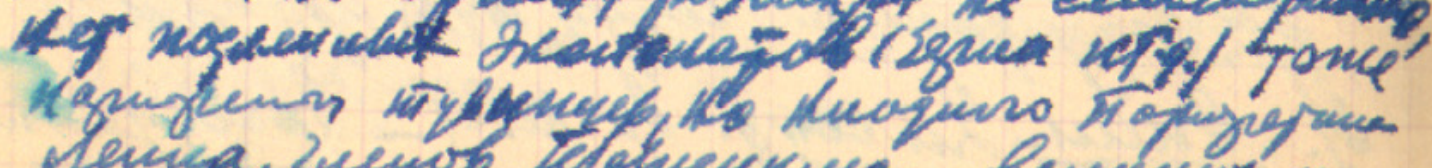

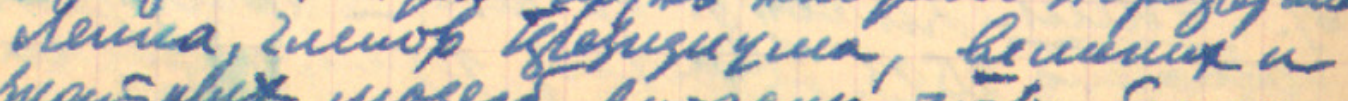

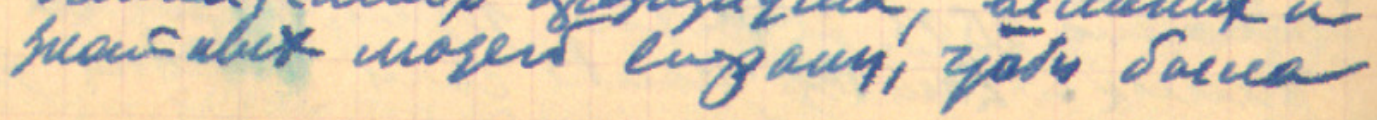

Рис. 5. Страница 1 из дневника № 76 (17.08.1962-02.02.1963) о посещении музея 20 декабря 1962 г. Fig. 5. Page 1 from diary No. 76 (17.08.1962-02.02.1963) with an entry describing a visit to a museum, December 20, 1962. 
НОВЫЕ ИССЛЕДОВАНИЯ ТУВЫ

www.nit.tuva.asia

№4

2017

THE NEW RESEARCH OF TUVA

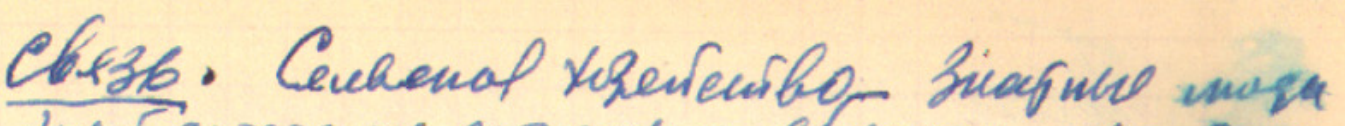

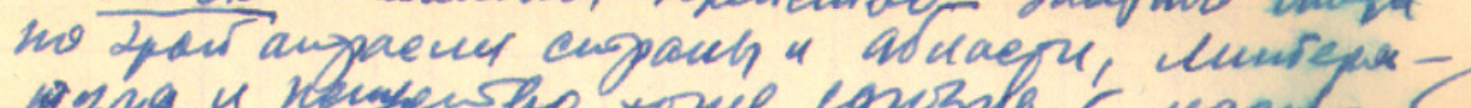

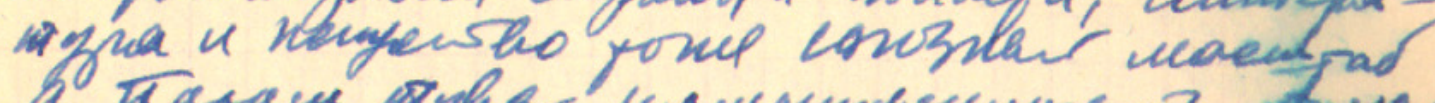

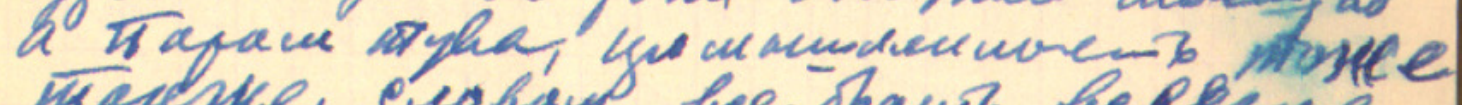

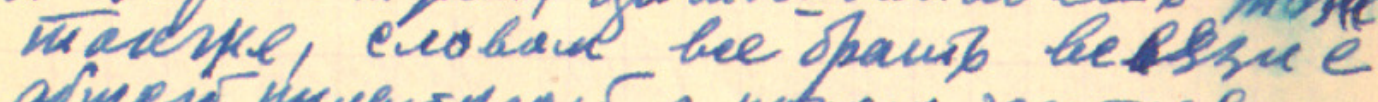

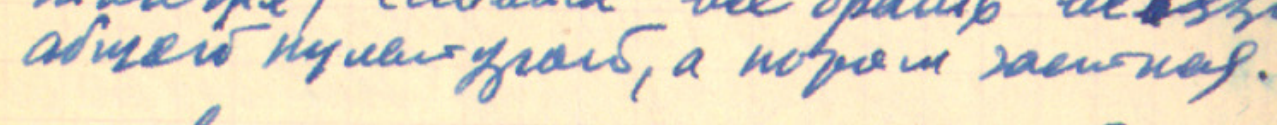

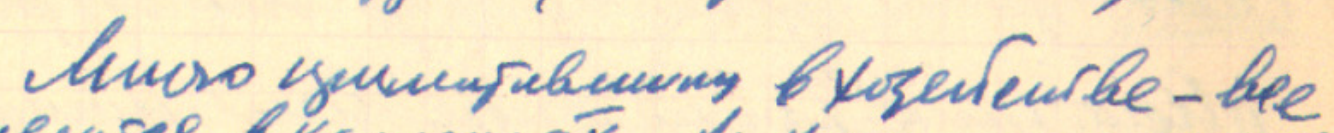
havsenges kgurgeate, the yunereng no noph

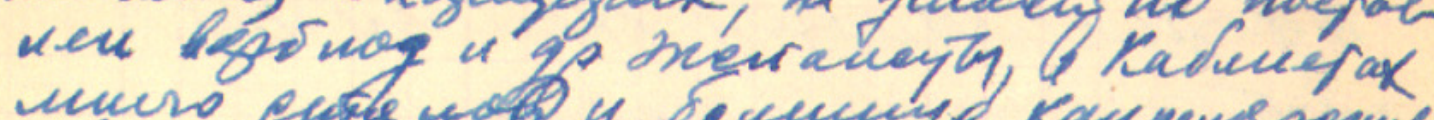

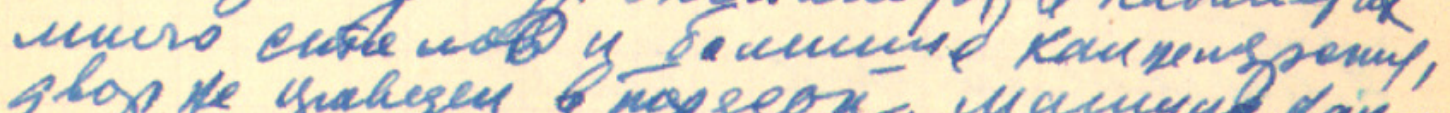

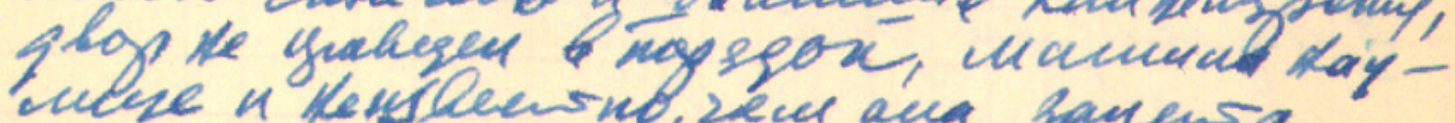

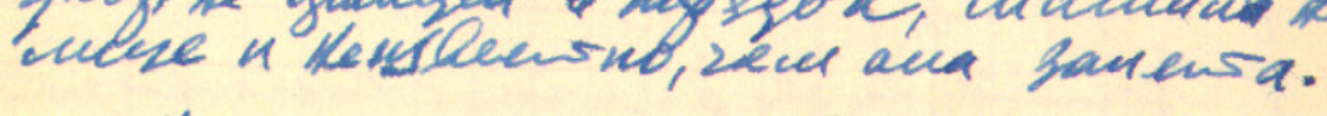

Hur nozar prenañ curenenoro ими

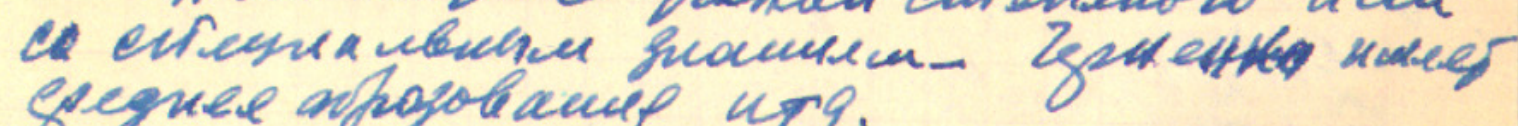
gsegnee arfogolacuip ugg.

the r menxa quy jrongung qaugob, sqane

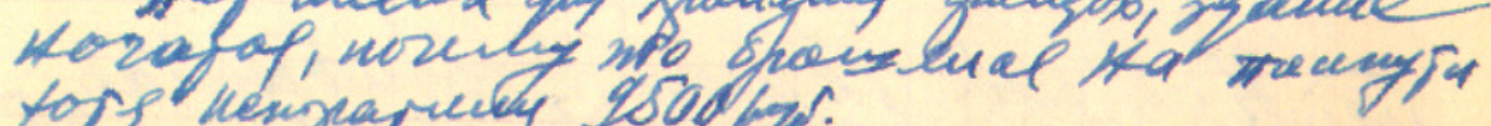
tors nengeapenes $2500 \mathrm{hr}$.

havo spanuspor asseqhumuse bhevers bum

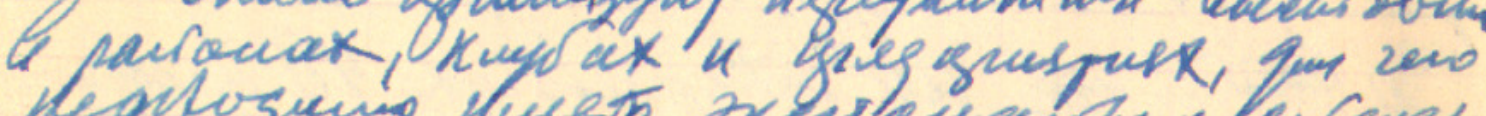

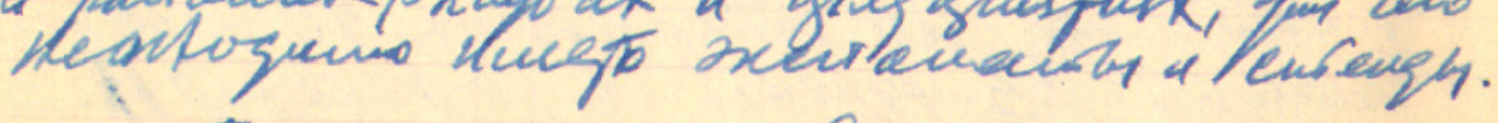

Boranse nueauts liresafy a genax

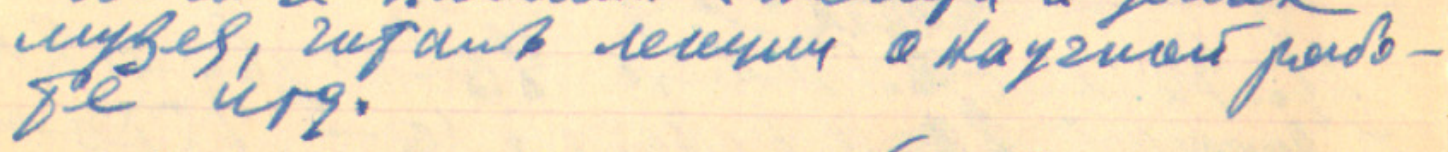

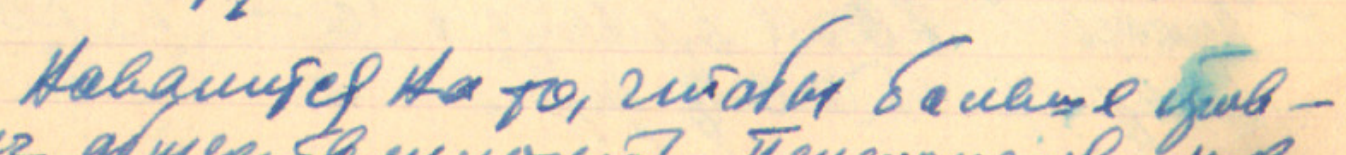
dez al meens burnonerb, Kenenauginb upg. nik uad ugaw uyges.

Рис. 6. Страница 2 из дневника № 76 (17.08.1962-02.02.1963) о посещении музея 20 декабря 1962 2. Fig.6. Page 2 from diary No. 76 (17.08.1962-02.02.1963) with an entry describing a visit to a museum, December 20, 1962.

86 
Из всего этого хочется отметить, что большинство школьных коллективов, учителей, общественности, в вопросах установления связи школы с жизнью, учебы с производителями труда, проделана большая работа и чувствуется, что к новому учеб. году в городе, все готово....

Мы надеемся, что вся городская общественность, наши педагоги сделают все для того, чтобы все дети были охвачены учебой, не допустят отсева» (рис. 7).

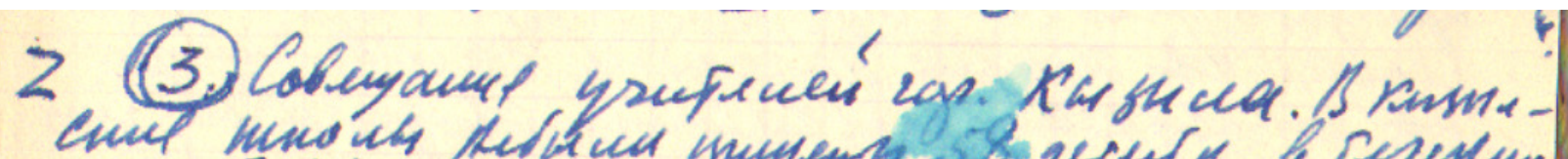

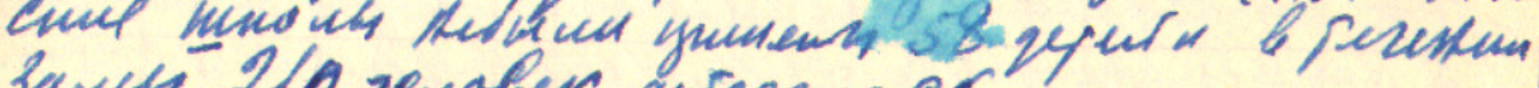

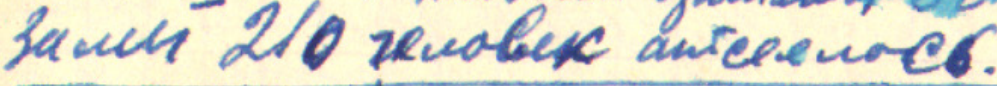

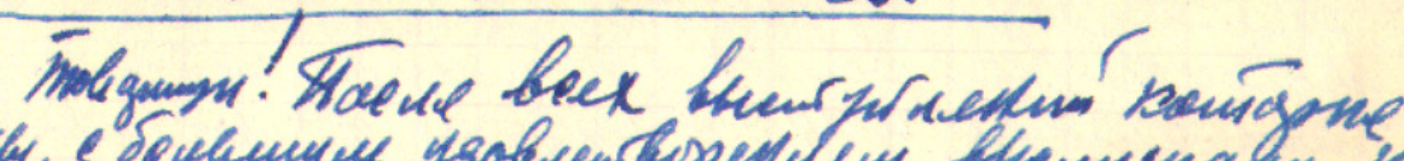

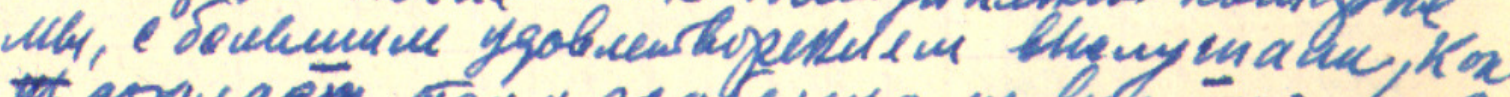

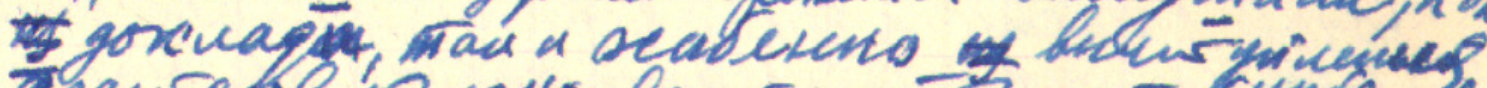

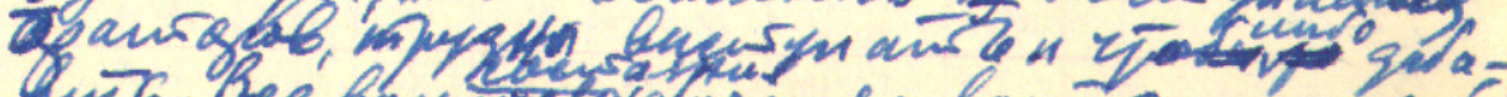

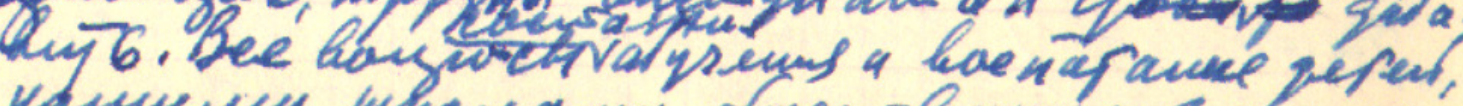

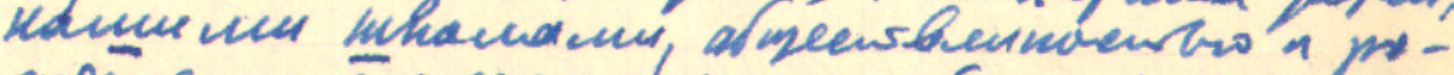

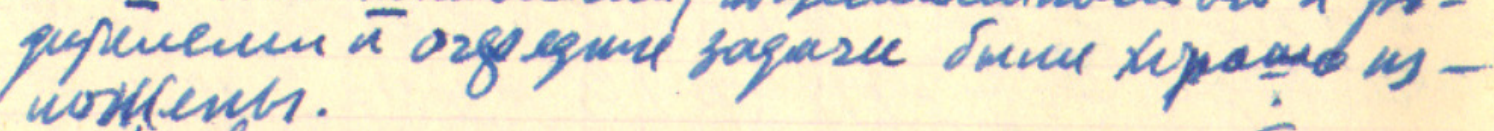

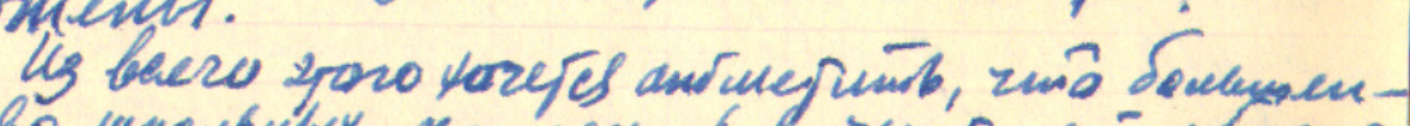

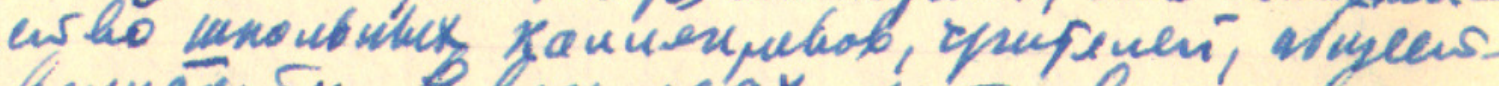

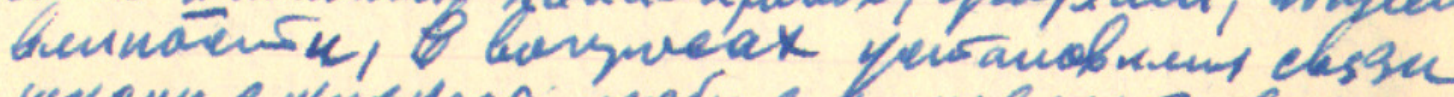

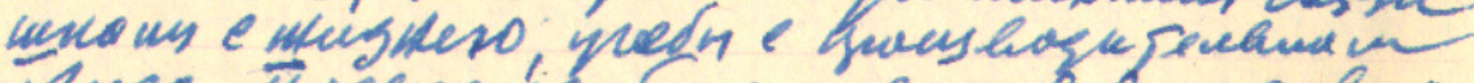

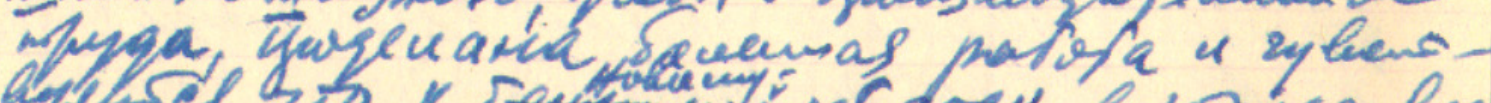

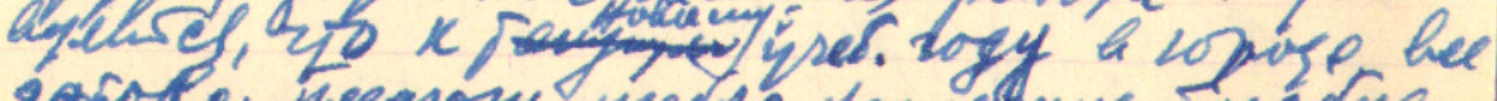

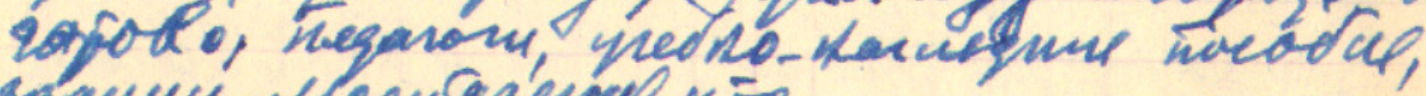

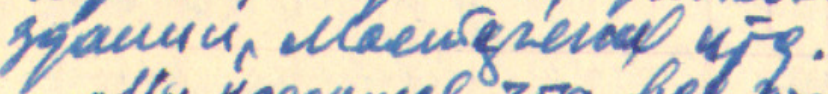

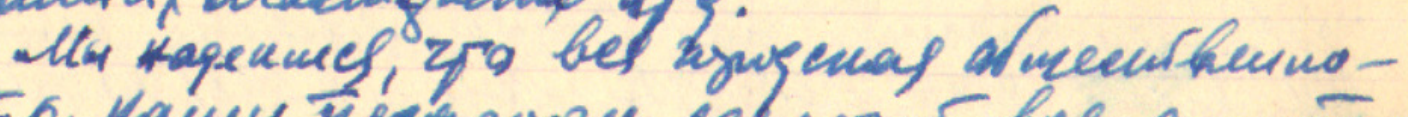

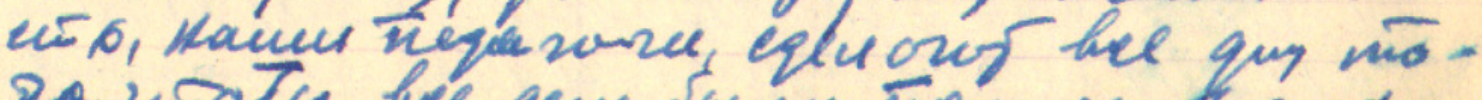
20, unotm bre quy bucu now ox -

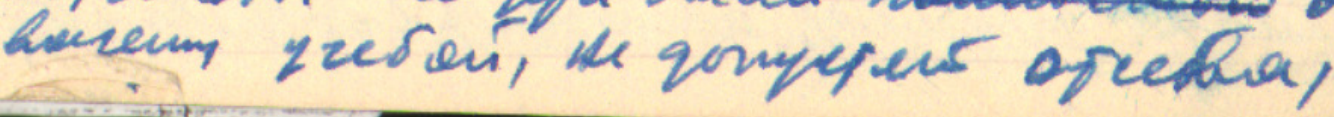

Рис. 7. Страница из дневника № 76 (17.08.1962-02.02.1963) об участии в совещании учителей 2. Кызыла 27.08.1962 г.

Fig. 7. A page from diary No. 76 (17.08.1962-02.02.1963) with an entry describing a teacher's conference in Kyzyl, August 27, 1962. 
Добивался увеличения объема общественных фондов для республики, за счет которого осуществлялось пенсионное обеспечение, выплата пособий и стипендий, бесплатное лечение и образование, оплата отпусков, путевок в санатории и дома отдыха, содержание детей в детских дошкольных учреждениях.

Бесспорным итогом переустройства быта, роста материального благосостояния, развития медицины, в которые вложено много заботы и труда С. К. Тока, является рост численности тувинского населения - к началу 1970 гг. в 2,5 раза по сравнению с 1944 г., а также увеличение средней продолжительности жизни всего населения до 66 лет. Республика в основном перешла к всеобщему среднему образованию, подготовила большой отряд специалистов для разных отраслей экономики, социально-культурных сфер.

\section{Идеологические вопросы}

В дневниках Тока можно прочитать о том, какое большое внимание он уделял повышению роли общественных структур - профсоюзных, комсомольских, женских организаций, органов народного контроля и других в осуществлении экономических, социально-культурных задач. Он видел, где каждая из них могла больше проявить себя, внести наибольший вклад в общем деле развития. Как обычно, он часто встречался с их руководителями и активом, бывал на официальных мероприятиях - конференциях и пленумах, слушал и подробно записывал выступления их участников, ставил перед ними конкретные задачи. Здесь следует сказать об особом внимании С. К. Тока к комсомолу, улучшению партийного руководства им, подготовке молодых кадров.

Запись от 27 ноября 1958 г. (дневник № 62):

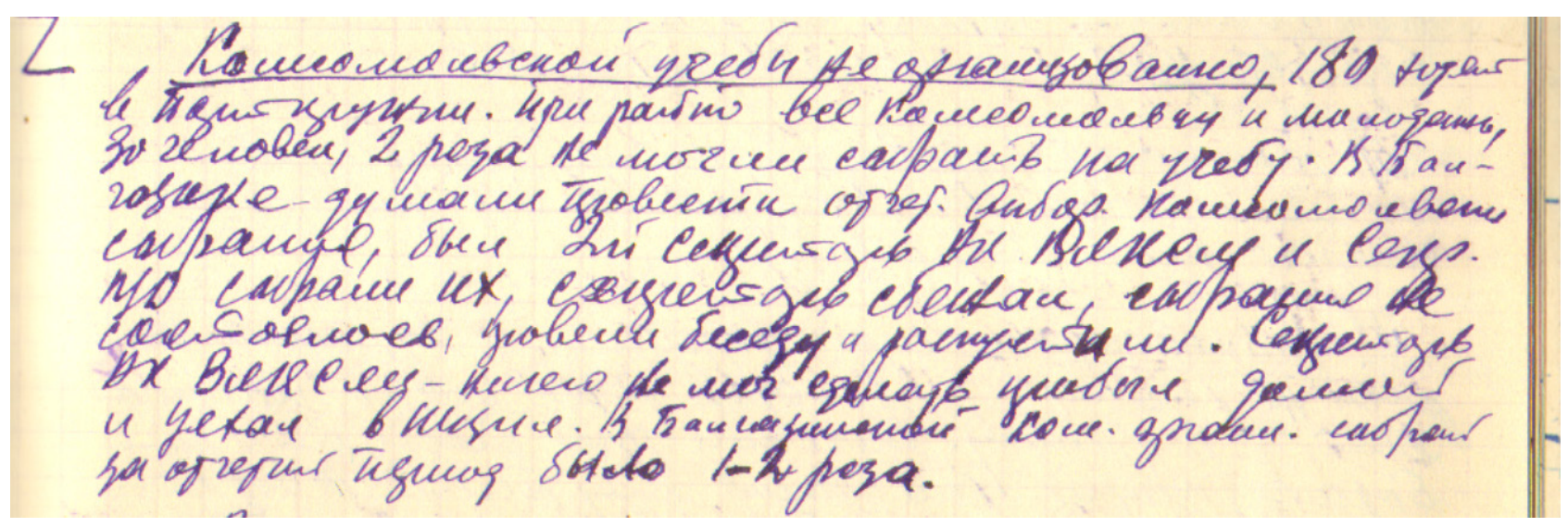

Рис. 8. Отрывок из дневника № 76 (17.08.1962-02.02.1963) о плохой работе комсомольской организации в одном из районов.

Fig. 8. A fragment from an entry criticizing the work of a Komsomol branch in one of Tuva's raions, diary No. 76 (17.08.1962-02.02.1963) 
«Комсомольской учебы не организовано. 180 юрт в парткружки. При райпо все комсомольцы и молодежь, 30 человек, 2 раза не могли собрать на учебу. $B$ Балгазике думали провести отчет. выбор. комсомольское собрание, был 2-й секретарь РК ВЛКСМ и секр. п/о собрали их, секретарь сбежал, собрание не состоялось, провели беседу и распустили. Секретарь РК ВЛКСМ - ничего не мог сделать прибыл домой и уехал в Кызыл. В Балгазинской ком. орган. собраний за отчетный период было 1-2 раза» (рис. 8).

Его интересовали не только трудовые дела молодых людей, в частности, в возведении горнорудных комбинатов, строительстве социальных объектов, в развитии животноводства и земледелия, но и вопросы их быта и досуга, он посещал молодежные общежития, организуемые культурно-спортивные мероприятия.

С. К. Тока всегда подчеркивал важную роль идеологической, массово-политической работы в деле мобилизации трудящихся на осуществление хозяйственно-экономических, социальных задач. В блокнотных записях имеются масса конкретных фактов и примеров, как он настраивал партийные комитеты, их работников и актив на повышение уровня организации и повышение качества систем политического просвещения и экономической учебы рабочих и колхозников без отрыва от производства, работы общества «Знание», групп докладчиков и агитаторов.

Запись от 6 января 1959 г. (дневник № 62):

«2. Бегзи (Чаа-Холь). Партполитработа идет плохо, отдельные клубы холодные, не подготовлены. ...»

Для повышения трудовой и политической активности трудящихся настаивал повсеместно использовать организацию социалистического соревнования, движения «За коммунистический труд», ударничества пятилеток, профессиональные слеты, «Доски Почета», «Флаги трудовой славы», стенгазеты и т. д. В работе с народом особая роль отводилась газетам «Тувинская правда», «Шын», «Тыванын аныяктары», «За коммунистический труд», «За асбест», районным газетам (рис. 9).

С. К. Тока, исходя из глубокого понимая важнейшей роли Коммунистической партии в осуществлении общественных, хозяйственно-экономических, социально-культурных преобразований в Туве, будучи первым секретарем обкома КПСС, делал все для организационно- политического укрепления партийной организации. Понятно, что успешное решение задач в большой степени зависело от уровня постановки работы с руководящими кадрами. Поэтому, его постоянной заботой была подготовка и закрепление кадров, создание резервов на руководящие должности не только в партийных структурах, но и в основных звеньях советских и хозяйственных органов. В блокнотах содержатся многочисленные записи о встречах и предметных разговорах с кадрами, нацеливание их на деловитость и ответственность за порученное дело, улучшение рабо- 
ты с людьми и т. д. В то же время, понимая, что они решали непростые, порою сложные задачи, С. К. Тока всегда сочетал требовательность с товарищеской чуткостью и уважительным отношением к людям.

В работе с кадрами он постоянно подчеркивал важность глубокого изучения решений съездов КПСС, пленумов ЦК, использование передового опыта партийных комитетов других областей и республик в конкретных местных условиях. О его серьезном отношении к решениям высших партийных органов,

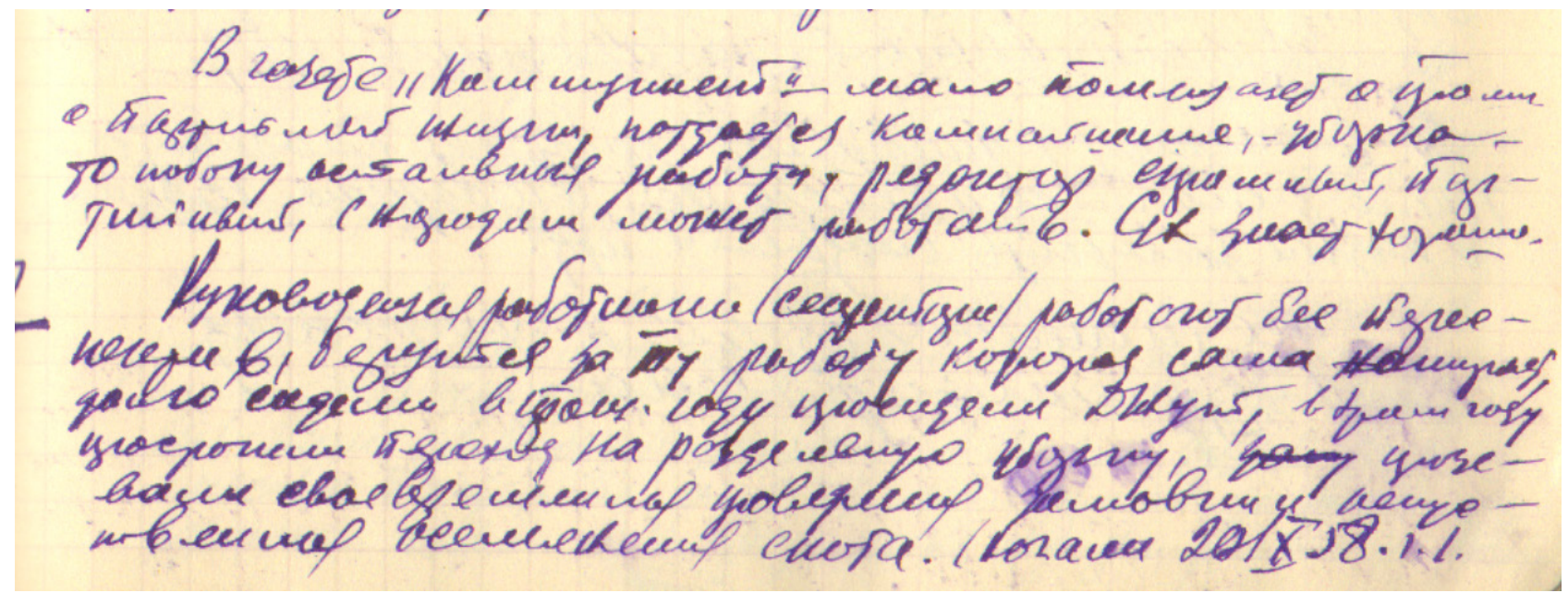

Рис. 9. Страница из дневника № 76 (17.08.1962-02.02.1963) о проблемах газеты «Коммунист». Fig. 9. A page from diary No. 76 (17.08.1962-02.02.1963) with an entry on the problems of the Kommunist newspaper

опыту других показывают подробные конспектные записи в блокнотах-дневниках. Тока постоянно следил за материалами в газетах «Правда», «Советская Россия», «Сельская жизнь», журналах «Коммунист» и «Партийная жизнь», рекомендовал руководящим работникам читать и использовать в работе отдельные, по его мнению, полезные публикации.

С. К. Тока придавал большое значение проведению в республике общественно-политических мероприятий, посвященных В. И. Ленину, Октябрьской Социалистической революции, 8 марта и 1 мая, другим общегосударственным праздникам. Конечно же, в поле его постоянного внимания также находились дни вхождения Тувы в состав СССР и ее преобразования в Тувинскую АССР.

Из блокнотов можно узнать о том, какое пристальное внимание он уделял формированию новой системы и структуры вновь организованной Тувинской АССР в соответствии с законодательством СССР и РСФСР. Прежде всего, была проведена большая организационная работа по формированию первого депутатского корпуса из числа самых известных и активных представителей народа и проведению выборов в Верховный Совет при заинтересованном активном участии избирателей. А затем, при непосредственном участии самого С. К. Тока 
состоялась первая сессия Верховного Совета по избранию его руководящих органов. Он, приветствуя депутатов, напомнил им о важности их работы в деле дальнейшего развития республики, большой ответственности перед народом.

В своей работе Тока не ограничивался исключительно делами республики, он с большим интересом вникал в проблемы международной деятельности, выступая с докладами на партийных и общественных мероприятиях. Он уделял внимание укреплению дружественных связей Тувы с приграничными аймаками Монголии, сам не один раз посещал их, приглашал и встречался с их руководителями.

\section{Заключение}

С. К. Тока обладал творческим стилем и методом работы. Об этом убедительно свидетельствуют записи в блокнотах.

В работе был исключительно аккуратным, четко планировал каждодневную работу по решению самых разных вопросов текущего и перспективного характера. В блокнотах имеются много таких пометок: «Вопросы на завтра», «Рассмотреть и обсудить», «Дать поручение», «Вопросы перед Москвой», «Пригласить и поговорить», «Позвонить», «Побывать» и т. д.

С. К. Тока обладал замечательными личными качествами: обладал даром объединять людей, умением организовать работу кадров, был очень внимательным к запросам и нуждам людей, особенно рядовым труженикам, был доступным и простым в общении. Твердым его правилом был регулярный личный прием граждан, которые приходили к нему с самыми разными социально-бытовыми просьбами, критически высказывали свое отношение к работе отдельных организаций и учреждений, руководящих работников, поднимали проблемы общественной жизни. Он не оставлял без внимания ни одну из их просьб и обращений. С. К. Тока умел поднимать настроение людей, любил шутить, образно выражаться.

Блокноты являются ценным источником в исследовании многогранной деятельности С. К. Тока, показывают его огромную роль в общественно-политическом, хозяйственно-экономическом и социально-культурном переустройстве жизни тувинского народа, выведении Тувы на всесоюзную, всероссийскую арену.

В народе, особенно в среде старшего и среднего поколений Тувы в целом еще крепко сохраняется память и воспоминания о советском периоде развития республики, созидательных делах народа, их вдохновителях и организаторах, к числу которых в первую очередь относится С. К. Тока. К сожалению, молодое поколение в силу известных факторов и условий плохо или вообще не знают об этом. Поэтому очень важно, чтобы в работе с молодежью, детьми, их воспитании долж- 
ное место уделялось советской истории родного края, ее неразрывная связь с настоящим и будущим. В этом деле мы считаем дневниковые записи Салчака Калбакхорековича Тока одним из важных инструментов воспитания подрастающего поколения и можем рекомендовать их для подготовки отдельным изданием.

\section{СПИСОК ЛИТЕРАТУРЫ}

Аранчын, Ю. Л. (1982) Исторический путь тувинского народа к социализму. Новосибирск : Наука. 340 с.

Ламажаa, Ч. К. (2010) Клановость в политике регионов России. Тувинские правители. СПб. : Алетейя. 208 с.

Москаленко, Н. П. (2002) Этнополитическая история Тувы XX века. М. : Наука. 222 c.

Байыр-оол, М. С. (2009) Сын своего времени [Электронный ресурс] // Новые исследования Тувы. № 1-2. URL: https://nit.tuva.asia/nit/article/view/672 (дата обращения: 01.07.2017).

Байыр-оол, М. С. (2010) Уникальный опыт вертикальной мобильности // Социологические исследования. № 2. С. 141-148.

Байыр-оол, М. С. (2011) Три столпа тувинской государственности [Электронный ресурс] // Новые исследования Тувы. № 2-3. URL: https://nit.tuva.asia/nit/ article/view/404 (дата обращения: 01.07.2017).

Салчак Тока в истории и современности (2012) [Электронный ресурс] // Новые исследования Тувы. № 1. URL: https://nit.tuva.asia/nit/article/view/362 (дата обращения: 01.07.2017).

Тока, С. К. (1951) Слово арата / пер. с тув. М. : Гослитиздат. 120 с.

Дата поступления: 07.10.2017 2.

\section{REFERENCES}

Aranchyn, Iu. L. (1982) Istoricheskii put' tuvinskogo naroda $k$ sotsializmu [The historical path of the Tuvan people to socialism]. Novosibirsk, Nauka. 340 p. (In Russ.).

Lamazhaa, Ch. K. (2010) Klanovost'v politike regionov Rossii. Tuvinskie praviteli [The clan politics of Russia's regions. The Leaders Of Tuva]. St. Petersburg, Aleteiia. 208 p. (In Russ.).

Moskalenko, N. P. (2002) Etnopoliticheskaia istoriia Tuvy XX veka [Ethno-political history of Tuva in the XX century]. Moscow, Nauka. 222 p. (In Russ.).

Baiyr-ool, M. S. (2009) Syn svoego vremeni [The son of his times]. The New Research of Tuva, no. 1-2 [online] Available at: https://nit.tuva.asia/nit/article/view/672 (access date: 01.07.2017). (In Russ.). 
Baiyr-ool, M. S. (2010) Unikal'nyi opyt vertikal'noi mobil'nosti [A unique experience of upward mobility]. Sotsiologicheskie issledovaniia, no. 2, pp. 141-148. (In Russ.).

Baiyr-ool, M. S. (2011) Tri stolpa tuvinskoi gosudarstvennosti [The three pillars of Tuvan statehood]. The New Research of Tuva, no. 2-3 [online] Available at: https:// nit.tuva.asia/nit/article/view/404 (access date: 01.07.2017). (In Russ.).

Salchak Toka v istorii i sovremennosti (2012) [Salchak Toka in history and today]. The New Research of Tuva, no. 1 [online] Available at: https://nit.tuva.asia/nit/article/ view/362 (access date: 01.07.2017). (In Russ.).

Toka, S. K. (1951) Slovo arata [The word of an Arat] / transl. from Tuv. Moscow, Goslitizdat. 120 p. (In Russ.).

Submission date: 07.10.2017.

\section{Для цитирования:}

Ширшин Г. Ч. Летопись советской Тувы 1950-1960-х гг. в дневниках Салчака Тока [Электронный ресурс] // Новые исследования Тувы. 2017, № 4. URL: https://nit. tuva.asia/nit/article/view/739 (дата обращения: дд.мм.гг.). DOI: 10.25178/nit.2017.4.4

\section{For citation:}

Shirshin G. Ch. A Chronicle of the Soviet Tuva (1950s-1960s) in the Diaries of Salchak Toka. The New Research of Tuva, 2017, no. 4 [on-line] Available at: https:/nit.tuva.asia/nit/ article/view/739 (accessed: ... ). DOI: 10.25178/nit.2017.4.4 